\title{
The Potential of Microbial Symbionts Macrotermes gilvus Hagen Termite Gut as Degrading Agents of Cellulose in Bioethanol Production
}

\author{
Dewi Susilowati, ${ }^{\bowtie}$ Niken Subekti, Siti Harnina Bintari \\ DOI: http://dx.doi.org/10.15294/biosaintifika.v10i2.14965
}

Department of Biology, Faculty of Mathematics and Natural Science, Universitas Negeri Semarang, Indonesia

\section{History Article}

Received 7 April 2018

Approved 12 June 2018

Published 30 August 2018

\section{Keywords}

Bioethanol; Degrading agent of cellulose; Macrotermes gilvus Hagen; Microbial symbionts inside the termite's gut

\begin{abstract}
Water hyacinth is a potential feedstock for bioethanol production because of their high cellulose. The microbial symbionts of the Macrotermes gilvus termite's gut have a high endoglucanase enzyme activity. This research was aimed to analyze the $\mathrm{pH}$, temperature and agitation effects towards cell density, endoglucanase enzyme activity and reducing sugar, and to determine the effective optimum condition that can produce maximum reducing sugar. This research used central composite design (CCD) with the total number of run was. The independent variables were including $\mathrm{pH}$ $(5.9,6.4,7.0,7.6,8.0)$, temperature $\left(30^{\circ} \mathrm{C}, 33^{\circ} \mathrm{C}, 37{ }^{\circ} \mathrm{C}, 41{ }^{\circ} \mathrm{C}, 44{ }^{\circ} \mathrm{C}\right)$ and agitation (90 rpm,114 rpm, $150 \mathrm{rpm}, 185 \mathrm{rpm}, 210 \mathrm{rpm}$ ), with six replications at central points. Parameters measured were cell density, endoglukanase enzyme activity and reducing sugar, thus analyzed by the statistical software package MINITAB 18.0. The Student's t-test result showed the primary sequence influencing cell density as $\mathrm{pH}>$ agitation $>$ temperature and towards endoglucanase enzyme activity and reducing sugar as $\mathrm{pH}>$ temperature $>$ agitation, $\mathrm{P}<0.05$. The maximum reducing sugar $\left(60.13 \pm 3.16 \mathrm{mmolL}^{-1}\right)$ was obtained at $\mathrm{pH} 6.95$, temperature $37^{\circ} \mathrm{C}$ and agitation $150 \mathrm{rpm}$. The results of this research can be used to explore the more potential microbial symbionts of the Macrotermes gilvus Hagen termite's gut.
\end{abstract}

\section{How to Cite}

Susilowati, D., Subekti, N., \& Bintari, S. H. (2018). The Potential of Microbial Symbionts Macrotermes gilvus Hagen Termite Gut as Degrading Agents of Cellulose in Bioethanol Production. Biosaintifika: Journal of Biology \& Biology Education, 10(2), 395-400.

(C) 2018 Universitas Negeri Semarang

\footnotetext{
Correspondence Author:
}

Sekaran, Gn. Pati, Semarang, Jawa Tengah 50229, Indonesia

E-mail: nikensubekti@mail.unnes.ac.id

p-ISSN 2085-191X

e-ISSN 2338-7610 
Dewi Susilowati, Niken Subekti, Siti Harnina Bintari / Biosaintifika 10 (2) (2018) 395-400

\section{INTRODUCTION}

Bioethanol is one of potential energy sources that can be developed as renewable fuel and eco-friendly. Current bioethanol development has switched using lignocellulosic biomass, such as water hyacinth (Eichhornia carssipes). It is because the abundant availability of water hyacinth and does not compete with edible and also it has a high cellulose yield (Das et al., 2016).

As a bioethanol feedstock, water hyacinth should be de-lignified to degrade and remove lignin and hemicellulose from cellulose. The next step is saccharification to depolimerate complex sugar into simple sugar. Delignification can dissolve more hemicellulose and increase the amount of cellulose that in the sample of delignification can produce cellulose $(35,4 \%)$ and hemicellulose $(19,6 \%)$ while in the sample of non-delignification can only produce cellulose $(24,7 \%)$ and hemicellulose (32,2\%) (Das et al., 2016). It shows that delignification is important, that is why the water hyacinth in this research was delignified with $\mathrm{H}_{2} \mathrm{SO}_{4}(2 \%$, v/v) under steam at a constant temperature $\left(121^{\circ} \mathrm{C}\right)$ for $20 \mathrm{~min}$ as same as the research of Reales-Alfaro et al. (2013).

The de-polymerization of cellulose into glucose and hemicellulose into glucose, manose, and xilose need complex celullolytic enzyme (Sánchez et al., 2011). It becomes a consideration in developing bioethanol because $40-60 \%$ from the total etanol production cost for commercial enzyme purchases (Dhillon et al., 2012). Thus, many researchers tried to reduce the production cost, as a substituting commercial enzyme by microbial symbionts of the Macrotermes gilvus Hagen termite's gut. Macrotermes gilvus Hagen is higher termite which identified have two cellulolytic microbial of termite gut symbionts that have high cellulotic activities, Bacillus megaterium and Paracoccus yeei (Ferbiyanto et al., 2016)

On other hand, one of the effort to reduce the production cost by combining sacarification and fermentation steps into single step (simultaneous saccharification and fermentation (SSF)). SSF is more economical comparing with separate hydrolysis and fermentation (SHF) because the time needed to produce reducing sugar is shorter yet still can increase hidrolysis rates thus requiring lower enzyme loadings and also having low rate of contaminating risk (Sudiyani et al., 2014; Scully \& Orlygsson 2015). Thus, many factors of SSF, such as $\mathrm{pH}$, temperature and agitation, are urgently necessary to be optimized by central composite design (CCD) to increase enzyme production (Deka et al., 2013).
This aims of this research were to analyze the $\mathrm{pH}$, temperature, and agitation effects towards cell density value, endoglucanase enzyme activity, and reducing sugar and also to determine the effective optimum condition that can produce maximum reducing sugar.

\section{METHODS}

\section{Preparation and delignification of water hya- cinth biomass}

Fresh water hyacinth was collected from a Rawa Pening lake, Ambarawa, Semarang. It is washed to remove impurities. The leaves and stems $(7 \mathrm{~kg}$ each) were dried separately. Drying is done for $\pm 7 \mathrm{~d}$. The water hyacinth is chopped and ground using a grinding machine with a 0.6 $\mathrm{mm}$ sieve. After that, the applying of delignification as the method of Reales-Alfaro et al. (2013). Then, there was a Chesson (Datta 1981) assay step towards the delignification result filtrate and the last cellulose with amount of $42.24 \pm 0.24 \%$ was obtained as bioethanol feedstock.

\section{Preparation of the microbial symbionts of the Macrotermes gilvus Hagen termite's gut}

Live termites were taken from Semarang State University mini forest. It were collected in a clean jar bottles (Subekti \& Febriana 2016). After that one hundred Macrotermes gilvus caste worker termites was sterilized with $70 \%$ ethanol $(\mathrm{v} / \mathrm{v})$ (Tay et al., 2010). Termite guts were taken aseptically using micro-tweezers and suspended at 1 $\mathrm{mL} \mathrm{NaCl}(0.85 \%, \mathrm{w} / \mathrm{v})$ (Sharma et al., 2015). The suspension was further centrifuged at $95 \mathrm{~g}$ in 1 $\min$ (Tay et al., 2010). Then, $0.5 \mathrm{~mL}$ aliquots were cultured with $4.5 \mathrm{~mL}$ of liquid medium I (Sharma et al., 2015), followed by incubation at $30^{\circ} \mathrm{C}$ for $7 \mathrm{~d}$. Then $1 \mathrm{~mL}$ result of spread plate culture on sterile solid medium (Dickerman \& Starr 1951), followed by incubation at $30^{\circ} \mathrm{C}$ for $24 \mathrm{~h}$. While microbial screening was performed by culturing the inoculum obtained from spread plate on 50 $\mathrm{mL}$ of the second liquid medium (Sharma et al., 2015 modified without CMC) and incubated at $30{ }^{\circ} \mathrm{C}$ for $72 \mathrm{~h}$.

\section{Preparation of Saccharomyces cerevisiae}

Saccharomyces cerevisiae was obtained by culturing Fermipan $(10 \%, w / v)$ in the second liquid medium (Sharma et al., 2015 modified without CMC) and incubated at $30{ }^{\circ} \mathrm{C}$ for $72 \mathrm{~h}$ (Jumiyati et al., 2012; Kurniawan et al., 2014).

\section{Optimization SSF factors}

Filtrates of $1.5 \mathrm{~g}$ were added in the er- 
lenmeyer and added $80 \mathrm{~mL} 0.05 \mathrm{M}$ buffer $\mathrm{pH}$ $\mathrm{KH}_{2} \mathrm{PO}_{4}-\mathrm{NaOH}(5.9,6.4,7.0,7.6,8.0)$ and 20 $\mathrm{mL}$ microbes $(30 \%, \mathrm{v} / \mathrm{v})$ (the microbial symbionts of the Macrotermes gilvus Hagen termite's gut-Saccharomyces cerevisiae, ratio 1:1), those were shaked with shaker for $24 \mathrm{~h}$ at temperature $\left(30^{\circ} \mathrm{C}\right.$, $\left.33{ }^{\circ} \mathrm{C}, 37{ }^{\circ} \mathrm{C}, 41^{\circ} \mathrm{C}, 44^{\circ} \mathrm{C}\right)$ and agitation $(90 \mathrm{rpm}$, $114 \mathrm{rpm}, 150 \mathrm{rpm}, 185 \mathrm{rpm}, 210 \mathrm{rpm})$. Then, the suspension (the cell density measurement) was sentrifused at $2400 \mathrm{~g}$ for $20 \mathrm{~min}$ to seperate filtrate and supernatant (to endoglucanase enzyme activity and reducing sugar assay).

\section{Cell density, endoglucanase enzyme activity and reducing sugar assay}

Cell density of the microbial symbionts of the Macrotermes gilvus Hagen termite's gut-Saccharomyces cerevisiae was done by using spectrophotometer UV-Vis (Parkin Elmer, Model lambda-45) at $\mathrm{OD}_{600 \mathrm{~nm}}$ (Sakolvaree \& Deevong 2016). Endoglucanase enzyme activity was done with $0.5 \mathrm{~mL}$ cell-free supernatant added with $0.5 \mathrm{~mL}$ CMC $(1 \%, \mathrm{w} / \mathrm{v})$ which was dissolved in buffer $\mathrm{pH} 7.0$, and then was incubated at $37^{\circ} \mathrm{C}$ for $30 \mathrm{~min}$. Reducing sugar assay was done based on standard method by using benedict quantitative reagent, and the absorbance measurement was done by using spectrophotometer UV-Vis (Parkin Elmer, Model lambda-45) at $\mathrm{OD}_{477 \mathrm{~mm}}$ (Sambo et al., 2015). The sample of reducing sugar was obtained by calculating $\chi$ value in a formula that was obtained from the measuring of standard solvent (glucose $0 \mathrm{mmolL}^{-1}, 2.5 \mathrm{mmolL}^{-1}, 5 \mathrm{mmolL}^{-1}, 7.5 \mathrm{mmolL}^{-1}$ and $10 \mathrm{mmolL}^{-1}$ ).

\section{RESULTS AND DISCUSSION}

Water hyacinth biomass as the result of the delignification that was used in this research obtained cellulose $42.24 \pm 0.24 \%$. Similar research that was conducted by Reales-Alfaro et al., (2013) was producing less cellulose with amount of $31.67 \%$. The different percentage of that lignocellulose component was reported by RealesAlfaro et al., (2013) that because the condition of nutrition habitate affect the metabolism process of the plant that generates different chemical characteristic. On the other hand, these differences might caused by the geographic location and growing condition of water hyacinth (Das et al., 2016).

After that, the cellulose was converted into glucose by cellulase enzyme through simultaneous saccharification and fermentation (SSF). In this research, cellulase enzyme was obtained from the microbial symbionts of the Macrotermes gilvus Hagen termite's gut which was optimized on some factors such as $\mathrm{pH}$, temperature and agitation by central composite design (CCD). The advantage of CCD is representatif in showing optimum condition with less run amount (Montgomery 2013).

Actual and prediction values (from the result of data CCD analyzing) for cell density value, endoglucanase enzyme activity and reducing sugar from the result of SSF sample testing, were presented in Table 1.

Based on the Table 1, it showed that the mean of actual value from those three responses had considered small difference towards the prediction value, thus can be indicated that those three responses has valid value. On the other hand, the testing result of Student's t-test showed that the influence of $\mathrm{pH}$ and agitation towards cell density value was significantly different while the temperature had influence that was not too different from the value of $\mathrm{P} \square 0.05$. Those results mean that the influence of $\mathrm{pH} \square$ agitation $\square$ temperature towards cell density value. Yet the result of Student's t-test for endoglucanase enzyme activity and reducing sugar shows that only $\mathrm{pH}$ wich has significant different, while the temperature and agiation indicated insignificance. It means that $\mathrm{pH} \square$ temperature $\square$ agitation, towards endoglucanase enzyme activity and reducing sugar.

The result of the optimization confirmed that $\mathrm{pH}$ has most effect towards cell density value, endoglucanase enzyme activity and reducing sugar. It is because $\mathrm{pH}$ influences many chemical reaction by affecting chemical product transport and enzyme that are passing through cell membrane (Liang et al., 2010). Similar research about the influence of $\mathrm{pH}$ towards cell density and endoglucanase enzyme activity was reported by Deka et al. (2013) and Sakolvaree \& Deevong (2016).

The influence of $\mathrm{pH}$ towards cell density value could be seen from the maximum respond that reach $3.50 \pm 0.13 \mathrm{selmL}^{-1}$ (prediction value). It showed that microbial symbionts of Macrotermes gilvus termite's gut was optimum on considered neutral $\mathrm{pH}$. That microbes included in neutrophil microbes with the rate of $\mathrm{pH}$ around 5.5-8.0. Sakolvaree \& Deevong (2016) explained that microbial symbionts of termite gut can live far below its optimum $\mathrm{pH}$ and some of bacteria symbionts reported forming endospore which help the bacteria in it to survive and improve their ability to live in high temperature and extreme condition. That is related with the range of termite gut $\mathrm{pH}$ where the microbial symbionts 
Dewi Susilowati, Niken Subekti, Siti Harnina Bintari / Biosaintifika 10 (2) (2018) 395-400

Table 1. Actual and prediction value for cell density $\left(\operatorname{selmL}^{-1}\right)$, endoglucanase enzyme activity (UmL $\left.{ }^{1}\right)$ and reducing sugar $\left(\mathrm{mmolL}^{-1}\right)$

\begin{tabular}{|c|c|c|c|c|c|c|}
\hline \multirow[t]{2}{*}{ Codes } & \multicolumn{2}{|c|}{ Cell density (selmL $\left.{ }^{-1}\right)$} & \multicolumn{2}{|c|}{$\begin{array}{l}\text { Endoglucanase enzyme } \\
\text { activity }\left(\mathrm{UmL}^{-1}\right)\end{array}$} & \multicolumn{2}{|c|}{$\begin{array}{l}\text { Reducing sugar } \\
\left(\mathrm{mmolL}^{-1}\right)\end{array}$} \\
\hline & Actual & Prediction & Actual & Prediction & Actual & Prediction \\
\hline $\mathrm{A}_{-1} \mathrm{~B}_{-1} \mathrm{C}_{-1}$ & $3.22 \pm 0.0$ & & $0.003 \pm 0.0$ & & $16.07 \pm 0.0$ & $22.28 \pm 4.12$ \\
\hline $\mathrm{A}_{1} \mathrm{~B}_{-1} \mathrm{C}_{-1}$ & $65 \pm 0.0$ & $2.76 \pm 0.26$ & $0.006 \pm 0.0$ & $0.006 \pm 0.00$ & $35.00 \pm 0.0$ & $30.22 \pm 4.19$ \\
\hline $\mathrm{A}_{-1} \mathrm{~B}_{1} \mathrm{C}_{-1}$ & & & $0.005 \pm 0.0$ & & $25.42 \pm 0.0$ & \\
\hline $\mathrm{A}_{1} \mathrm{~B}_{1} \mathrm{C}_{-1}$ & $3.85 \pm 0.0$ & & $0.004 \pm 0.0$ & $0.006 \pm 0.00$ & $22.62 \pm 0.0$ & $32.98 \pm 4.19$ \\
\hline $\mathrm{A}_{-1} \mathrm{~B}_{-1} \mathrm{C}_{1}$ & $87 \pm 0.0$ & $4.23 \pm 0.26$ & $0.003 \pm 0.0$ & $0.004 \pm 0.00$ & $15.18 \pm 0.0$ & $19.98 \pm 4.10$ \\
\hline $\mathrm{A}_{1} \mathrm{~B}_{-1} \mathrm{C}_{1}$ & & $3.46 \pm$ & $.005 \pm$ & & 28.04 & \\
\hline $\mathrm{A}_{-1} \mathrm{~B}_{1} \mathrm{C}_{1}$ & $4.56 \pm 0.0$ & $4.23 \pm 0.26$ & $0.004 \pm 0.0$ & $0.004 \pm$ & $24.23 \pm 0.0$ & $=4.10$ \\
\hline $\mathrm{A}_{1} \mathrm{~B}_{1} \mathrm{C}_{1}$ & & & $0.004 \pm 0.0$ & & & \\
\hline $\mathrm{A}_{-1,68} \mathrm{~B}_{0} \mathrm{C}_{0}$ & & & $0.005 \pm$ & & & \\
\hline $\mathrm{A}_{1,68} \mathrm{~B}_{0} \mathrm{C}_{0}$ & $1.90 \pm 0.0$ & $2.90 \pm 0$ & $0.009 \pm c$ & $0.008 \pm c$ & $48.81 \pm 0.0$ & $44.97 \pm 5.88$ \\
\hline $\mathrm{A}_{0} \mathrm{~B}_{-1,68} \mathrm{C}_{0}$ & $3.85 \pm 0.0$ & $3.50 \pm 0.13$ & $0.004 \pm 0.0$ & $0.004 \pm 0.00$ & $22.62 \pm 0.0$ & $20.81 \pm 6.13$ \\
\hline $\mathrm{A}_{0} \mathrm{~B}_{1,68} \mathrm{C}_{0}$ & $3.73 \pm 0.0$ & $3.50 \pm 0.1$ & $0.005 \pm c$ & $0.005 \pm 0.00$ & $28.33 \pm 0.0$ & 25.64 \\
\hline $\mathrm{A}_{0} \mathrm{~B}_{0} \mathrm{C}_{-1,68}$ & $2.53 \pm 0.0$ & $2.91 \pm 0.30$ & $0.004 \pm 0.0$ & $0.005 \pm 0.00$ & $24.11 \pm 0.0$ & $23.36 \pm 5.97$ \\
\hline $\mathrm{A}_{0} \mathrm{~B}_{0} \mathrm{C}_{1,68}$ & $4.75 \pm 0.0$ & $4.09 \pm 0.30$ & $0.004 \pm 0.0$ & $0.003 \pm 0.00$ & $22.20 \pm 0.0$ & $18.17 \pm 6.07$ \\
\hline $\mathrm{A}_{0} \mathrm{~B}_{0} \mathrm{C}_{0}$ & $2.87 \pm 0.0$ & $3.50 \pm 0.13$ & $0.011 \pm 0.0$ & $0.011 \pm 0.00$ & $56.85 \pm 0.0$ & $60.13 \pm 3.16$ \\
\hline $\mathrm{A}_{0} \mathrm{~B}_{0} \mathrm{C}_{0}$ & & & $0.009 \pm c$ & & $48.75 \pm$ & $60.13 \pm 3.16$ \\
\hline $\mathrm{A}_{0} \mathrm{~B}_{0} \mathrm{C}_{0}$ & $3.04 \pm 0.0$ & $3.50 \pm 0.13$ & $0.012 \pm 0.0$ & $0.011 \pm 0.00$ & $62.80 \pm 0.0$ & $60.13 \pm 3.16$ \\
\hline $\mathrm{A}_{0} \mathrm{~B}_{0} \mathrm{C}_{0}$ & $4.22 \pm 0.0$ & $3.50 \pm 0.13$ & $0.011 \pm 0.0$ & $0.011 \pm 0.00$ & $61.43 \pm 0.0$ & $60.13 \pm 3.16$ \\
\hline $\mathrm{A}_{0} \mathrm{~B}_{0} \mathrm{C}_{0}$ & $3.05 \pm 0.0$ & $3.50 \pm 0.13$ & $0.014 \pm 0.0$ & $0.011 \pm 0.00$ & $78.04 \pm 0.0$ & $60.13 \pm 3.16$ \\
\hline $\mathrm{A}_{0} \mathrm{~B}_{0} \mathrm{C}_{0}$ & $3.31 \pm 0.0$ & $3.50 \pm 0.13$ & $0.010 \pm 0.0$ & $0.011 \pm 0.00$ & $52.68 \pm 0.0$ & $60.13 \pm 3.16$ \\
\hline
\end{tabular}

Description: ${ }^{*}$ ) the values were obtained from the OD cell density mean multiplied by dissolving factors (mean $\pm \mathrm{SD}, \mathrm{n}=3$ ); **) the values were obtained from the formula standard curva; , while $\mathrm{Y}$ is the value of $O D$ reducing sugar and $X$ is the value of reducing sugar; ${ }^{* * *}$ ) the values were obtained from the formula: , while $\mathrm{Y}$ is enzyme activity, $\mathrm{C}$ is reducing sugar concentration, $\mathrm{Fp}$ is the serial dilution, $\mathrm{T}$ is the time of incubation and MW is the molecule weight

breed. Brune \& Ohkuma (2011) reported that the $\mathrm{pH}$ of Cubitermes termite's gut are crop ( $\mathrm{pH} 4.0$ ), midgut ( $\mathrm{pH}$ 4.0-7.0), mixed segment $(\mathrm{pH} 7.0-$ 12.0), pouch ( $\mathrm{P} 1)(\mathrm{pH} 12.0), \mathrm{P} 3(\mathrm{pH} 8.0-12.0), \mathrm{P} 4$ ( $\mathrm{pH}$ 6.0-8.0) and $\mathrm{P5}$ ( $\mathrm{pH}$ 4.0-6.0).

Cell density value showed the amount of microbes cells that can produce endoglucanase enzyme. That enzyme has a function to hidrolise CMC that has crystaline structure and hard to dissolve in the water and become the source of carbon needed as the energy and ability to growth (Sakolvaree \& Deevong 2016).

Microbial symbionts of Macrotermes gilvus termite's gut are the consortium microbes including Bacillus megaterium, Bacillus flexus, Bacillus coreensis, Bacillus abyssalis, Bhargavaea cecembensis, Paenisporosarcina indica, Planococcus fifietoensis, Paracoccus huijuniae, Paracoccus aminovorans, Paracoccus denitrificans, Paracoccus thiocyanatus, Paracoc- cus yeei, Oceanicola marinus, Sulfitobacter donghicola, Donghicola eburneus (Ferbiyanto et al., 2016). Bacillus reported by König et al., (2013) has cellulase activity to degrade cellulose, 1,4- $\beta$-xylanase and $1,3-\beta$-galactanase activities to degrade hemicellulose, $\beta$-glucosidase activity to oxidize C6 sugar, $\beta$-D-galactosidase, $\alpha$-L-arabinosidase, $\beta$-Lxylosidase activities to oxidize C6 and C5 sugar, and also has an ability to oxidize aromatic components as same as role of Enterobacter, Klebsiella, Pseudomonas, and Serratia. Bacillus has higher endoglucanase enzyme activity with amount of $138.77 \mathrm{Ug}^{-1}$ (Kamsani et al., 2015). As same as Ferbiyanto et al., (2016) explained that Bacillus megaterium and Paracoccus yeei have highest cellulolytic activity.

Besides the influence of $\mathrm{pH}$, agitation is also confirmed more affecting in obvious towards cell density value than the temperature, otherwise 
temperature factor is more affecting the endoglucanase enzyme activity value and reducing sugar compare with agitation factor. It is because microbial symbionts of Macrotermes termite's gut included in obligate aerob and facultative anaerob that needs oxygen in their growing rate (Ferbiyanto et al., 2016; Muwawa et al., 2016). On the other hand, temperature is affecting cell division (Black \& Black 2015), and also affecting the secretion extracellular enzyme by transforming cell membrane physically (Sharma et al., 2015). Lai et al., (2015) also reported that reducing sugar concentration is increasing at temperature $35-45{ }^{\circ} \mathrm{C}$ because catalyst enzyme is reacting faster when the temperature is increasing. It corresponds with surface plot curve (Figure 1) which shows that the maximum value of reducing sugar is at temperature $37^{\circ} \mathrm{C}$.

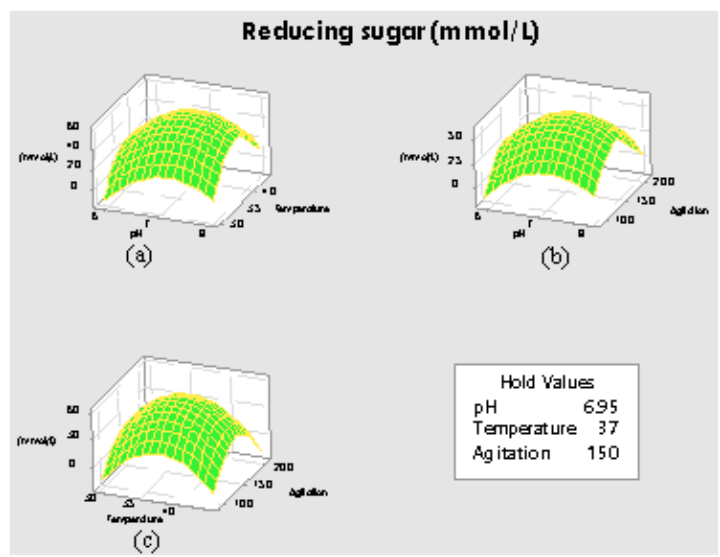

Figure 1. Interaction of (a) $\mathrm{pH}$ and temperature, (b) $\mathrm{pH}$ and agitation, (c) temperature and agitation towards the value of reducing sugar $\left(\mathrm{mmolL}^{-1}\right)$ on a maximum point

Figure 1 shows that the maximum value of reducing sugar is obtained in $\mathrm{pH} 6.95$, temperature $\left(37^{\circ} \mathrm{C}\right)$ and agitation $(150 \mathrm{rpm})$, with amount of $60.13 \pm 3.16 \mathrm{mmolL}^{-1}$. Reducing sugar was obtained by converting cellulose by cellulase enzyme. It means that reducing sugar is asociated with cellulase enzyme activity especially $\beta$-glucosidase enzyme which have a role in converting cello-oligosaccharide or gluco-oligosaccharide into reducing sugar. On the other hand, cello-oligosaccharide is obtained from the random excision of internal bound of cellulose chain by endoglucanase enzyme (Manavalan et al., 2015).

Saccharomyces cerevisiae in this research was used as fermentative yeast to degraded glucose into ethanol. Fermentative yeast, such as Saccharomyces sp., has growing characterictic on the base of the medium and forming sediment in the growing assay by Sabouraud Broth (SB) medium (Jumiyati et al., 2012). The limitation of Saccharomyces as fermentative yeast is only be able to degrade reducing sugar such as, glucose, fructose, and sucrose into ethanol, acetate, lactate acid and many others (Scully \& Orlygsson 2015). While Chansoliya et al. (2016) explained that Saccharomyces cerevisiae was reported is more potential to be used as fermentation microbes than Zymomonas mobilis.

\section{CONCLUSION}

The result of the research shows that $\mathrm{pH}$ is really influencing towards the amount of cell density which is asociated with endoglucanase enzyme activity and reducing sugar. Agitation is more affecting after $\mathrm{pH}$ towards the amount of cell density than temperature, and so the otherwise for endoglucanase enzyme activity and reducing sugar. It is corresponding with the optimizing result of optimum condition that showed the maximum amount of reducing sugar which was $60.13 \mathrm{mmolL}^{-1}$ in $\mathrm{pH} 6.95$ at temperature (37 $\left.{ }^{0} \mathrm{C}\right)$ and agitation (150 rpm).

\section{ACKNOWLEDGEMENT}

Thank you for the Research, Technology, and Higher Education Ministry which has been funding and facilitating the implementation of this research through students creativity programe 2015 .

\section{REFERENCES}

Black, J. G. \& Black, L.J. (2015). Microbiology principles and explorations. Ninth edition. Amerika: John Wiley \& Son.

Brune, A. \& Ohkuma, M. (2011). Diversity, structure and evolution of the termite gut microbial community. Biology of Termite: a Modern Synthesis, 413-438).

Chansoliya, P. R., Anand, R. \& Sharma, S. (2016). Analysis of bioethanol production from newspaper by Saccharomyces cerevisiae and Zymomonas mobilis. International Journal of Engineering Development and Research, 4(2), 517-519).

Das, A., Priyanka, G., Tanmay, Uma, G., Bikas, R. P. \& Keshab, C. M. (2016). Production of bioethanol as useful biofuel through the bioconversion of water hyacinth (Eichhornia crassipes). 3 Biotech, 6:70.

Datta, R. 1981). Acidogenic fermentation of lignocellulose-acid yield and conversion of components. Biotechnology and Bioengineering XXIII, 2167-2170.

Deka, D., Das, S. P., Sahoo, N., Das, D., Jawed, M., 
Goyal, D. \& Goyal, A. (2013). Enhanced cellulase production from Bacillus subtilis by optimizing physical parameters for bioethanol production. Hindawi Publishing Corporation ISRN Biotechnology (2013, 1-11).

Dhillon, G. S., Brar, S. K., Kaur, S., Metahni, S. \& M'hamdi, N. (2012). Lactoserum as moistening medium and crude imducer for fungal cellulose and hemicellulose induction through solid-state fermentation of apple pomace. Biomass Bioenergy, 41,165-174).

Dickerman, J. M. \& Starr, T. J. 1951). A medium for the isolation of pure cultures of cellulolytic bacteria. J bacterial, 62, 133-134).

Ferbiyanto, A., Rusmana, I. \& Raffiudin, R. (2016). Characterization and identification of cellulolytic bacteria from gut worker Macrotermes gilvus. Hayati Journal of Biosciences XXX,1-4).

Jumiyati, Bintari, S. H. \& Mubarok, I. (2012). Isolasi dan identifikasi khamir secara morfologi di tanah kebun wisata pendidikan Universitas Negeri Semarang. Biosaintifika Journal of Biology and Biology Education, 4(1), 27-35).

Kamsani, N., Salleh, M. M., Yahya, A. \& Chong, C. S. (2015). Production of lignocellulolytic enzyme by microorganism isolated from Bulbitermes sp. termite gut solid-state fermentation. Waste Biomass Valor, 1-15).

König, H., Li, L. \& Fröhlich, J. (2013). The cellulolytic system of the termite gut. Appl Microbiol Biotechnol, 97, 7943-7962).

Kurniawan, T. B., Bintari, S. H. \& Susanti, R. (2014). Efek interaksi ragi tape dan ragi roti terhadap kadar bioetanol ketela pohon (Manihot utilissima, Pohl) varietas Mukibat. Biosaintifika Journal of Biology and Biology Education, 6(2), 152-160.

Lai, L. W., Yahya, S. S. M., Nor, N. M. \& Sulong, M. R. (2015). Enzymatic saccharification on ammonia pre-treated oil palm trunk biomass for glucose production: an optimization using response surface methodology. Malaysian Journal of Analytical Sciences, (20(1), 21-30.

Liang, Y., Feng, Z., Yesuf, J. \& Blackburn, J. W. (2010). Optimization of growth medium and enzyme assay conditions for crude cellulases produced by a novel thermophilic and cellulolytic bacterium, Anoxybacillus sp. 527). Applied Biochemistry and Biotechnology, 160(6), 1841-1852).

Manavalan, T., Manavalan, A., \& Heese, K. (2015). Characterization of llignocellulolytic enzymes from white-rot fungi. Curr Microbiol, 70, 485498).

Montgomery, D. C. (2013). Design and analysis of experi- ments- eighth edition. Hoboken: John Wiley \& Sons, Inc.

Muwawa, E. M., Budambula, L. M., Osiemo, Z. L., Boga, H. I. \& Mokonde, H. M. Isolation and characterization of some gut microbial symbionts from fungus-cultivating termites (Macrotermes and Odontotermes spp.). African Journal of Microbiology Research,10(26), 994-1004).

Reales-Alfaro, J. G., Trujillo, L. T., Arzuaga, G., Castaño, H. \& Polo, A. (2013). Acid hydrolysis of water hyacinth to obtain fermentable sugars. CT\&F-Ciencia, Tecnologia y Futuro, 5(2), 101112).

Sakolvaree, J. \& Deevong. (2016). Isolation and characterization of cellulose producing bacteria from the gut of higher termite. Proceedings of the Burapha University International Conference (2016, 28-29 July (2016, Bangsaen, Chonburi, Thailand, 193-203).

Sambo, S., Faruk, U. Z. \& Shahida, A. A. (2015). Ethanol production from fresh and dry water hyacinth using ruminant microorganisms and ethanol producers. Global Advanced Research Journal of Biotechnology, 4(1), 023-029).

Sánchez, O., Sierra, R. \& Alméciga-Díaz, C. J. (2011). Delignification process of agro-industrial wastes an alternative to obtain fermentable carbohydrates for producing fuel. Intech, 112-154).

Scully, S. M. \& Orlygsson, J. (2015). Recent advances in second generation ethanol production by Thermophilic bacteria. Energies, 8, 1-30.

Sharma, D., Joshi, B., Bhatt, M. R., Joshi, J., Malla, R., Bhattarai, T. \& Sreerama, L. (2015). Isolation of cellulolytic organisms from the gut contents of termites native to Nepal and their utility in saccharification and fermentation of lignocellulosic biomass. Journal of Biomass to Biofuel, 2, 11-20.

Subekti, N. \& Febriana, F. (2016). The role of gut microorganisms from the subterranean termite Macrotermes gives Hagen during comoposting process. Proceedings of the $11^{\text {th }}$ Pacific Rim Termite Research Group Conference Kunming, China.

Sudiyani, Y., Sembiring, K. C. \& Adilina, I. B. (2014). Bioethanol G2: production process and recent studies. Biomass and Bioenergy: Processing and Properties, 345-364).

Tay, B. Y., Lokesh, B. E., Lee, C. Y. \& Sudesh, K. (2010). Polyhydroxyalkanoate (PHA) Accumulating Bacteria From The Gut of Higher Termite Macrotermes carbonarius (Blattodea : Termitidae). Journal Microbiology Biotechnology, 26(6), 1015-1024). 